\title{
Traits of leadership for efficacious communication of Project Management in Software Industry of Pakistan
}

\author{
Muhammad Ibrahim Abdullah \\ COMSATS Institute of Information Technology, Pakistan \\ Muddassar Sarfraz \\ Hohai University, Nanjing, PR China \\ Syed Murtaza Hussain Kazmi \\ COMSATS Institute of Information \&Technology (Virtual), Pakistan
}

\section{Introduction}

From 1930 to 1940 personality and appearance were considered better for a leader. In 1940 behavioral school of thoughts focused on leadership tasks and emphasized on learning leadership instead of an inborn trait. Different leadership ways for different leadership situations; by applying the skills owns by a Project Manager to the leadership situations; suggested by contingency school of thoughts

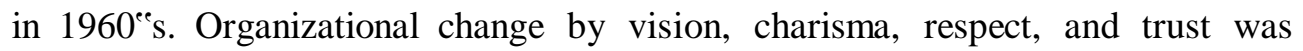
proposed by the Visionary and Charismatic School of thought in $1980^{\circ e}$. Muller and Turner in 2010 presented the emotional intelligence seminary. For the job triumph, the Individual potential of self-cognizance, self-organization, civic wakefulness and masses affiliation administration can be applied. Goleman, D. (2000). Emotional Intelligence is skilled those must be educated and this can result in an outstanding performance at work Goleman, D. (1998).

Emotional self-awareness is to know oneself and how one senses. John Mayer (Mayer and Stevens,

1994) used the term "meta-mood", the "effective analog of meta-cognition", for key features of Emotional Self-cognizance. Grazes in a discrete area of the neocortex discrimination damages facets of only rational capabilities such as spoken eloquence or exceptional cognitive (Damasio, 1994, 1999). In the $21^{\text {st }}$ century, need of leadership becoming high instead of just focusing on the managing 
the employees. So, communication becomes a vital role for a leader to impress the audience and to create new leaders. So studying the leadership has seen a great growth in recent years especially from the start of the new millennium (Hunter et al., 2007).

"Leadership Communication" a book composed by Deborah Barrett in 2006 takes together professional communication and notions of "emotive acumen" to create a novel model of communication abilities and policies for business leaders. Communication is essential to leadership, team, and stakeholders. Coaching is a leadership communication on an individual level increases the morale of a team.

This study presents the literature on leadership, qualities of leadership, communication, and leadership as communication. It gives a brief but comprehensive overview of what work has been done in this arena. Researchers and Authors have given good definitions and also highlighted different traits of a leader. Communication is one of those traits which is essential for all the Managers working in different industries but it becomes more vital in the context of Pakistani Software Industry which heavily relies upon the projects getting from off-shore businesses or customers. This study focuses on the three moderator variables: Trustworthiness, Candidness, and Fairness which if apply can moderate the behavior of a subordinate and can increase the moral of them to achieve high goals.

The role of the project managers at Pakistani Software houses is very limited and a demand of good project managers who have polished traits for better and effective communication along with an attitude which may establish an environment of growth and learning. Pakistani software Industry has a major contribution in terms of doing off-shore projects. So need becomes also very high to be the best project manager to encode or decode messages properly. Management in general and in specific to software industry is not to just drive resources to make profit but a way to extract the essence from them by considering the people and human by clear definitions, a brief but worthwhile communication and proper channels to make a good handsome sum of cash in a little period of time.

This study will redound the benefits to the researcher and Project Managers to uncover those major factors of a leader which lagged a Software Engineer for doing better. Study emphasis on "Effective leadership Communication for project managers in Pakistani software business in a typical bureaucratic and authoritarian managerial style." 


\section{Literature review}

\subsection{Concepts \& Definitions of a Leadership}

Many people define leadership in their own ways. Leadership cannot be defined in a single, unanimous term (Yukl, 2006) because different scholars "e aims are changed (Campbell, 1977, as mentioned in Yukl, 2006). The perspective of all of them is diverse or to some extent common to a leader for a better leadership to achieve some certain goals and objectives. Leadership is an influence; it is nothing more, nothing less. (John C. Maxwell, The 21 Irrefutable Laws of Leadership, 1998). Leadership is defined in terms of influence, role, behavior, attitude, traits of a leader and communication channels and communication power to deliver message properly and fairly (Stogdill in 1974 (and cited in Yukl 2006). A leader influences the masses around him by his acts, by his talks, personality and all the hidden guts he possesses to perform certain activities, to get some benefits out of hardships, to increase the morale of the team in an organization. It is important to know who is influencing, what the intention behind it is, how it was incurred and what were the results or gains (Yukl, 2006). It is something which an individual use to build relationships and to inspire others in order to change the behavior of the people around him. General Montgomery once stated that leadership is the dimensions and the determination to gather men and women to a shared and mutual objective and the charisma which stimulates sureness. It is an Individual behavior which directs the actions of a group to a mutual objective (Hemphill and Coons; 1957). Vecchio defined headship as: It is the gradual impact that a person has outside his or her official authority.

Leaders who influence require the support of the people who give power so that they can bring the change and achieve the set targets. Leadership necessitates by means of power to influence the opinions and activities of other persons. (Zalenik, A., Managers, and Leaders: are they different? Initially seemed in HBR May - June 1977 and reprinted in 1992). In $21^{\text {st }}$ millennium people only follows those who can instigate them towards their mutual purposes and needs.

Leadership is a stimulating connection between leaders and followers who target real changes that reflect their joint commitments (Joseph Rost, (1993). Leadership in the 21 st Century). Leaders are made to make a change. They create an environment where people can easily embrace the variations coming around. They promote ideas, new things and act in a way people started following them. Change is mid for an effective leadership. As big the change, the need for leadership will be as the big. Leadership demands such leaders who have a vision and future directions. 
Leadership describes what the imminent should look like, bring into line individuals with that dream, and encourages them to make it happen regardless of the hindrances. (John Kotter, (1996). Leading Change). Leader accelerates the change by constantly looking for opportunities, pinpoints the initiatives to capitalize on them and finish them fast to produce some results. Leadership is the art of activating others to need to fight for common ambitions (Kouzes, J.M., and Posner, B.Z., (2007). The Leadership Challenge ( $4^{\text {th }}$ Ed.)). Leadership is the course of coaxing or specimen by which a single (or leadership team) persuades a group to chase goals thought by the leader or distributed by the leader and his or her followers (John W. Gardner, (1993), On Leadership).

Pure Leaders share, believe in services, character, development, fairness, and truthfulness. The first obligation of a leader is to outline truth, and the last is to say thank you to the followers. In amid the two, the leader must become a helper and a pledger. That summarizes the development and growth of a creative leader." (Max DePree). "Leadership is not an individual or a situation. It is a multifaceted ethical connection among persons, centered on trust, duty, assurance, emotion, and a mutual vision of the good (Ed. Ethics, Joanne B. Ciulla, the Heart of Leadership, 2nd edition with a Preamble by James MacGregor Burns. Westport, CT: Praeger Issuers, 2004.) Leaders make other leaders instead of followers. They develop, encourage and promote people. Formerly you are a leader, achievement is all about developing yourself. When you come to be a leader, accomplishment is all about budding others. (Jack Welch).

Leadership flair depends upon personality, nature of the followers, circumstances, and environment where the leaders are. These factors define the way which style is to be adopted by the leader. Barret (2006) and Müller and Turner (2010), defined the leadership into six general categories: directive: authoritarian, commanding style in which project manager totally controls and keep the things in his hand, it is not a good style which just demotivates the people, pacesetting: meeting challenges and common purposes, participative: allowing team to make decisions by participating in different matters, visionary: leading a team towards a common interest in future for getting mutual benefits, coaching: Training and development become essential and Project Manager keeps on guiding, mentoring and coaching the others so that they may also get what they desire and affiliative: it creates co-ordination by joining team fellows, both one-on-one and in minor assemblages. Bureaucratic and laissez-faire were added by Kerzner (2009). The directive styles do not be considered good as in this case the total control remains with the leader. This style just discourages the employees instead of motivating them. The degree of a leader is not what you do, on the other hand, it is what folks do because of you (Howard Hendricks, (2013)). 
Project Managers working in the software industry where people sit and do work in a bound environment within the four walls must adopt the leadership styles to put up the complex and situational environment. Brits ( in separating the good from the great, 2009). Yang, Wu, Wang, and Chin (2010) also stresses to adopt styles which are according to conditions prevailing at the moment and it's the ability to assess the situation properly and timely so that actions can be taken by doing and effective communication.

In the $21^{\text {st }}$ century, leaders must be able to manage the increasing unpredictability by familiarizing new management styles. They must also act in an optimistic manner to help the followers to complete their tasks in hand in a stressful atmosphere.

Leaders challenge is to affect the followers" attitude and behavior so that they may stay motivated,

creative and productive at work through better communication. Project Managers as leader must keep themselves abreast of the internal and external factors affecting the better management. The organizations which invest in leader's development would bring fruits to the organization through influences such as enhanced organizational commitment, and job satisfaction (Ready \& Cogner, 2007). So the questions arise, which leadership styles and tools need to be developed and used to bring a positive healthy change? Leadership development must be aligned with Company's mission and values as well as planned goals and objectives (Riggio, 2008).

\subsection{Monocratic (Autocratic) Leadership}

An old and mostly used style which is popular in hierarchal organizations. A person sitting with vested authorities which he uses to order others. An authoritarian style is adopted in this type and close and strict monitoring is done of the subordinates. Decisions and made one-sided without involving the employees which leads towards speculations, lack of motivation and resentment. And poor communication is also the characteristic of this style.

\subsection{Autonomous (Democratic) Leadership}

One of the most effective leadership style which is opposite to the autocratic style. All members of an organization become part of the decision-making process but leader still executes the final verdict. It promotes open communication where subordinates share the ideas and both company and people get benefits. 
Subordinates think that they are also the part of the success of the company and they become creative.

\subsection{Laissez Faire (Free_-Rain) Leadership}

It was added by Kerzner (2009). It gives autonomy to the teammates to make decisions and leader does not directly participate in decision making unless requested by the subordinates. It loosens the control over employees and minimal control remains with the leader. A leader does delegate tasks to his/her subordinates. This is suitable if the subordinates are educated, know about the leadership and trustworthy to make good decisions for the betterment of the organization.

\subsection{Situational leadership}

Müller and Turner, (2010) mentioned that in this leadership style leaders adopt the characteristics according to the situations. This leadership style suggests that one cannot sustain for all the given situations (Leadership Journal, 2009). It brings devotion to the role of the subordinates David Wyld (2010). Leadership style variates according to the awareness and proficiency of followers of the leader in a given assigned task.

\subsection{Coaching leadership}

A leadership style in which a leader coaches the followers on a task instead of telling him what to do only. In this style, leader informs the followers how to cope with the issues and problems. Leader explains and answers of Whys, implores suggestions, also appraises the followers and continues to support them in the right directions to get the work done.

\subsection{Transformational leadership}

Timothy et al in 2011 defines this style in which leader encourages the subordinate's abilities and skills, focuses on trust, motivation, and know-how about making the most of his/her followers or subordinates. A project manager should transform himself first and then he must propel his followers" abilities by stirring them, it also depends on follower's skills, their attitude. Transformational leadership is completely correlated to disciples creativity followers' preservation, a worth, qualified that association and fundamental incentive mediated the involvement of the collaboration of transformational leadership and preservation and partly mediated the involvement of transformational leadership to vision (Shung Jae Shin1 and Jing Zhou, Washington State University, Rice University, 
2003). It is the most effective style being considered for the past few decades to understand the efficacy of a leader.

\subsection{Transactional leadership}

Transactional leadership emphases on the connections that occur between leaders and followers (Bass 1985; 1990; 2000; 2008; Burns, 1978), Policy and assembly of the organization (Geib and Swenson, 2013). It is a style that promotes, identifies the efforts, headword done by subordinates and their commitment to their work. It instigates subordinates to do well and achieving the targets and objectives set by the organization by giving some financial rewards (Rukmani et.al. 2010).

\subsection{Visionary Leadership}

For project-oriented industry, having a visionary leadership will be a blessing. Without the vision of the project, creativity is not possible and the chances are high of the failure. A project manager should think analytically about the project and must focus on and have a mindset of achieving goals. (Müller and Turner,

2010). A visionary leader must embroil the subordinates and followers in decision making, heeding to them, and communicating with them (Skipper and Bell, 2006).

\subsection{Path-goal leadership style}

A good Project manager becomes a good leader if he guides his subordinates about attaining the goals and he provides guidance and assistance to them in order to align goals according to the organization"s goals (Smith and Cronje, 2002). This theory was proposed by Robert House.

\subsection{Fiedler's leadership style}

In 1967 Fiedler explained a theory which emphasis on the leader personality and the situation aspects in the leadership situations. Smith and Cronje, in 2002 indicated that this theory is aligned with the Situational leadership style. Apply a style in accordance with the situation and change the situation according to the style.

\section{Project Manager's Traits}

An organization and particularly a software house should adapt themselves to adopt effective leadership development techniques for leadership and better performance for maximum gains (Amagoh, 2009). To keep themselves up to date and abreast of rapid and fast growing software industry and demands 
of the employees working at software houses, a leader must acquire more interpersonal skills along with better and effective communication to meet the challenges and future needs. A leader must acquire skills which include communication skills, interpersonal skills, problem-solving, stress handling and management skills. Ability to inspire and motivate others, and ability to do a better people management in order to develop them for achieving the goals of a project (Belzer, in Stevenson and Starkweather, 2009; Du Plessis, 2009b; Egeland, 2010; Steyn, 2008).

\subsection{Improve Self-awareness}

It is very important to know oneself. The weaknesses, the strengths of oneself of a leader are the important factors play an important role in better and effective communication. "Leaders require conducting a self-awareness examination or assessment to find self-strengths and flaws" (Dubrin, 2004). A project manager is a bonding agent which bonds the project and team and leads towards a success to achieve common goal and objectives. Success or failure of a project influenced by a leader or project manager"s skills (Styen, 2008).

\subsection{Appreciate individual differences}

A good leader appreciates other individuals" differences. At workplaces especially at software houses in the background of Pakistani industry, where IT hubs are centered to large cities and flux from other cities is very high to get jobs at a software house, creates a diverse and multi-ethnic environment. Leaders, especially global leaders, combat an extremely multifaceted, multi-ethnic world which requires appreciation of individual distinctiveness (Holt \& Seki, 2012).

\subsection{Apply general management rules}

The project manager should apply general manager rules for effective management. Different roles have been identified for a project manager such as "planning activities, tasks, schedules and budgets; organising, selecting and placing the project team; leading the project team; controlling activities and schedules; ability to select and develop a team and motivation of the team; communicating with the project team and all stakeholders; problem solving, decision making or knowledge where to find help; negotiating and persuading; and understanding the environment" (Baguley, 2010; Burke, 2003; Knipe, Van der Waldt, Van Niekerk, Burger and Nell, 2002; Steyn, 2008). 


\section{Motivating the team through effective communication and leadership}

For an effective leadership, motivating the team members is an important trait of a leader. Motivation requires command of effective and better communication. A right word at right time motivates dwindled and shaken employees whose work is affected and incarnate a new spirit into that person (Gilley, McMillan, and Gilley, 2009). This has also been discussed and presented in different kinds of literature and articles (Burke, 1992; Gill, 2003; Gilley, 2005; Sims, 2002; Ulrich, 1998). A motivated employee is better for an organization so it becomes vital for a leader to be motivator through communication and relevant ways.

\subsection{Leadership as a Communication trait}

Leadership as a function is getting the work done from others (Steyn, 2012). Leadership has a linkage with communication, delegating, and coordinating at all levels of management (Van der Walt, Strydom, Marx, and Jooste, 1996), which have a moderating effect on the aforesaid traits (Qureshi, 2009; Simmering, N.d.). So we can say leadership is a Communication Skill.

\subsection{Communication as a leadership skill}

For an organization and especially at software house where communication among the client, top management, and the team is vital because in order to implement the right thing and conveying the right message is very important. The company wants to implement its strategies, decisions, and values and for that purpose, a person sitting in a managerial position must communicate well.

\section{Theoretical/conceptual framework}

\subsection{Research Framework}

Leadership communication is a layered strategy which moves leader"s skills from core approach development: writing and speaking skills of a leader and to use these developed characteristics into a more complex and situational organizational environment (Barrett, 2006b). A project manager should develop core communication skills to become more effective in communication according to Barrett.

Demands of a more complex and effective communication of a Project manager becomes high as he is poised on higher positions at an organization. Barrett in 2006 also presented this idea and presented a spiral model instead of hierarchal 
(given in the appendix under section 7.1. Diagrams). The Barrett"s model presents three types of communications:

\subsection{Core Communication:}

Barrett considers „Writing and Speaking” skills the nucleus of the spiral model he introduced. Mastering these skills can lead towards the better and effective communication.

\subsection{Managerial Communication:}

Barrett next curve in his spiral is „managing others” which depends upon the core communication skills. This skill is required to interact with teams and groups.

\section{Corporate Communication:}

Barrett next curve of his spiral model is the external curve leads towards the corporate level communication. In this communication, one leads the organization to some higher post and communicates internal and external stakeholders.

This study uses a modified model of Barrett and introduces few moderator variables which should also be injected into the model upward, those are Trustworthiness, Candidness, and Fairness.

These moderator variables are applied at each communication level and relate it to the employees "Morale and productivity" which are the mediator variables increases or decreases by the conditional effect of these moderator variables. Communication as an Independent/predictor variable works well by using moderators and mediators on followers (Dependent/Criterion) variables. These three moderators increase the motivation, improves the communication and followers start believing in the leader and their words. If these moderators are missing and are not accentuated and highlighted separately, whatever the communication is done, that starts losing its impact on followers and trust in leaders. These moderators are very important in the context of Pakistani Software Industry. A conceptual model has been designed under the section of Conceptual Research model (Figure 3.1) which highlights that effective communication at each level in the professional progression as a leader; along with the upward direction of moderator variables which shows that as position improves, the need of trustworthiness, candidness, and fairness becomes higher. Because if the perception of a person poised at a high position becomes negative, it impacts the performance and mobility of the organization which results in loss and if that becomes positive, companies flourish. So the importance of such becomes very high in the Pakistani Software Houses background. 
Modified model first shows the important skills of a leader which includes selfawareness, appreciate individual difference in a team, apply general management, Leadership as communication trait, communication, and mobilize individual commitment. Self-awareness is a very important attribute of a leader.

Models based upon the "Barrett Spiral Communication Model (2006)"; and it has been discussed in detail in the previous section.

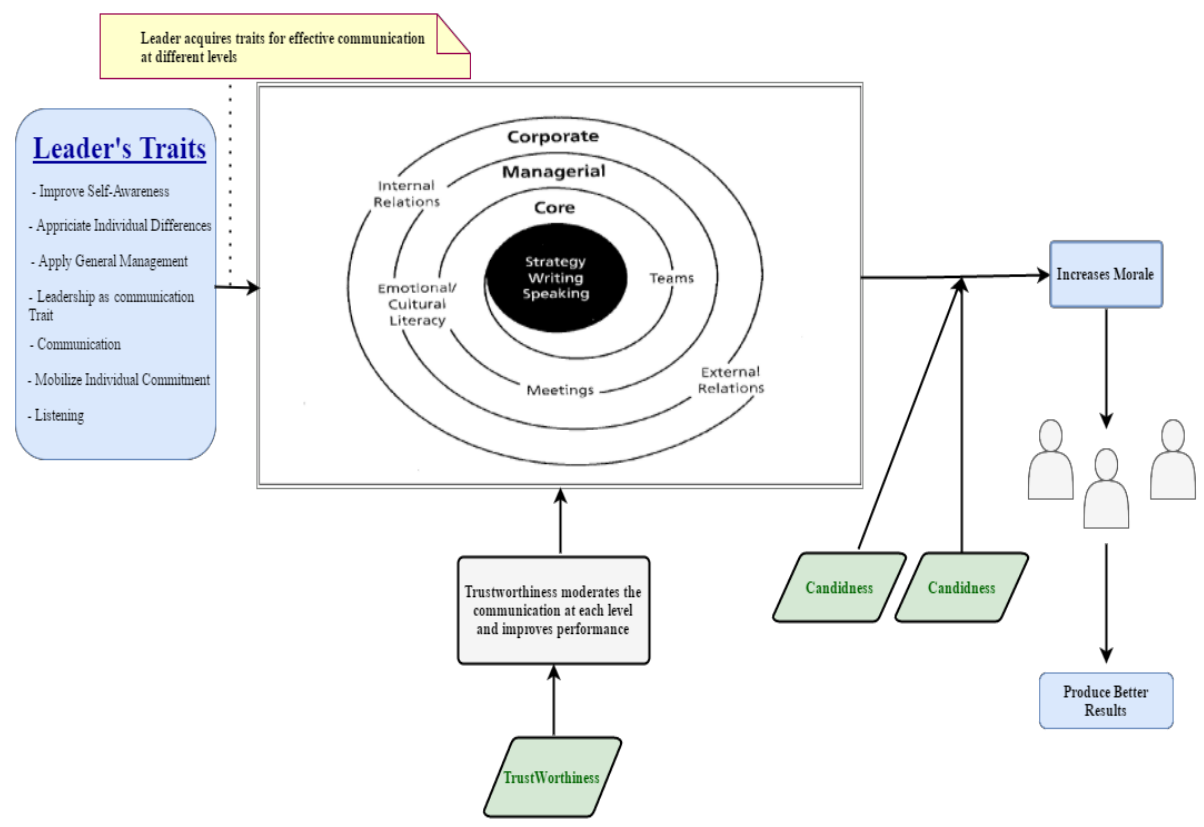

Figure 3.1: Leader's traits for Effective Communication

The population for collecting the sample for the survey was all the software houses, semi software houses in the two Major software hubs and Cities of Pakistan: Lahore and Karachi. The participants of this survey are the mix of Karachi and Lahore. Total 201 people responded and out of them, 150 records were chosen for the analysis purpose.

\subsection{Hypothesis Development}

H1: Leadership traits have a positive impact on communication at each level. 
H2: Trustworthiness in communication moderates the behavior of followers to produce better results.

H3: Effective communication with fairness and candidness increase the morale of

\begin{tabular}{lllll} 
Variables & Mean & Variance & Std. Deviation & No. of Items \\
People & 17.65 & 22.107 & 4.702 & 5 \\
\hline Development & & & & \\
Candidness & 10.47 & 9.298 & 3.049 & 3 \\
$\begin{array}{l}\text { Fairness (With } \\
\begin{array}{l}\text { Dropped } \\
\text { Questions) }\end{array}\end{array}$ & 10.71 & 7.374 & 2.715 & 3 \\
$\begin{array}{l}\text { Fairness (With } \\
\text { All Questions) }\end{array}$ & 16.33 & 12.032 & 3.469 & 5 \\
the followers & & &
\end{tabular}

Table 1: Reliability Statistics of Variables

The above table presents the reliability of the Variables. For Articulate/ Communication, Cronbach's alpha is .951 ( $\alpha \geq 0.9=$ Excellent), which designates a high level of internal consistency for our scale with this specific sample even if one item is deleted. All the other variables except Fairness have a high level of internal consistency. But it also shows that people were reluctant to give the answers about the fairness of the manager. Because fairness items had some contradictory statements which also became the reason of low Alpha. After removing the contradictory questions which had "never and not" words into them, were removed, we saw that internal consistency improved and came under acceptable range.

So overall the Reliability of the Scales or Instrument's items is high as most of the variables have strong Internal Consistency and the results are reliable. 


\begin{tabular}{lccc}
$\begin{array}{l}\text { Variables } \\
\text { Alpha }\end{array}$ & Cronbach's & $\begin{array}{l}\text { Cronbach's Alpha Based } \\
\text { on Standardized Items }\end{array}$ & N of Item \\
\hline $\begin{array}{l}\text { Articulate (Communication) } \\
\text { Trustworthy }\end{array}$ & .951 & .951 & 12 \\
Perceptive & .899 & .899 & 5 \\
People Development & .853 & .854 & 3 \\
Candidness & .890 & .891 & 5 \\
$\begin{array}{l}\text { Fairness } \\
\begin{array}{l}\text { Fairness (Recalculated } \\
\text { by removing questions } \\
\text { having negations) }\end{array}\end{array}$ & 0.707 & .819 & 3 \\
\hline
\end{tabular}

Table 2: Scale Statistics of Variables

\begin{tabular}{lcccc}
\multicolumn{1}{c}{ Variables } & Mean & Variance & Std. Deviation & No. of Items \\
\hline $\begin{array}{l}\text { Articulate } \\
\text { (Communication) }\end{array}$ & 44.32 & 114.702 & 10.710 & 12 \\
Trustworthy & 17.52 & 22.345 & 4.727 & 5 \\
Perceptive & 10.44 & 7.953 & 2.820 & $3 \mid$
\end{tabular}

Table 3: Model Summary

\begin{tabular}{|l|c|c|c|c|c|}
\hline & $\mathbf{R}$ & R Square & $\begin{array}{c}\text { Adjusted R } \\
\text { Square }\end{array}$ & $\begin{array}{c}\text { Std. Error of } \\
\text { theEstimate }\end{array}$ & $\begin{array}{c}\text { Durbin- } \\
\text { Watson }\end{array}$ \\
\hline 1 & $.762^{\mathrm{a}}$ & 581 & .578 & 2.92392 & 1.940 \\
\hline
\end{tabular}

Table 4: ANOVA Summary

\begin{tabular}{|l|l|l|l|l|l|l|}
\hline & Model & Sum of & df & Mean & F & Sig. \\
\hline
\end{tabular}


Muhammad Ibrahim Abdullah, Muddassar Sarfraz, Syed Murtaza Hussain Kazmi

\begin{tabular}{|c|l|c|c|c|c|c|}
\hline & & Squares & & Square & & \\
\hline 1 & Regression & 1754.674 & 1 & 1754.674 & 205.241 & $.000^{\mathrm{a}}$ \\
\hline & Residual & 1265.299 & 1 & 8.549 & & \\
\hline & Total & 3019.973 & 1 & & & \\
\hline \\
a. Predictors: (Constant), Trustworthy \\
b. Dependent Variable: Moderated Behaviour of followers \\
\hline
\end{tabular}

Table 5: ANOVA

\begin{tabular}{|c|c|c|c|c|c|c|}
\hline & Model & $\begin{array}{c}\text { Sum of } \\
\text { Squares }\end{array}$ & df & $\begin{array}{c}\text { Mean } \\
\text { Square }\end{array}$ & $\mathbf{F}$ & Sig. \\
\hline 1 & Regression & 11960.124 & 3 & 3986.708 & 113.450 & $.000^{\mathrm{a}}$ \\
\hline & Residual & 5130.516 & 146 & 35.141 & & \\
\hline & Total & 17090.640 & 149 & & & \\
\hline
\end{tabular}

Table 5 shows that our regression model is predicting the dependent variable "Articulate" very fine. ANOVA $(F(3,146)=113.450, p=.000)$. If we look at the significance given in the above table, we see that it is less than 0.0005 which is less than 0.05 and shows our model is statistically a good fit for the data and it significantly forecasts the dependent variable.

\section{Conclusion}

This study showed that in order to produce better results communication of the leadership has a very strong relationship and it comes great if employees are treated well. They are given rights to speak out, discuss matters, their thoughts and ideas are listening and appreciated. Further, this study suggests that by looking at the results that not all the traits are useful in different situations, a leader must adopt a style and trait according to the situation around him. At some stages, candidness under the umbrella of Trustworthiness works and sometimes fairness. But it is suggested, implied and verified that effective communication can never be achieved if the leader is not trustworthy, candid and fair in his dealings. 
The study concludes that everybody has abilities (inborn) to be a leader and to impress the followers by conveying their message. Every person in oneself is a leader to some extent, and if these skills are polished and a proper environment and a right education are provided to nurture them with a better, righteous, candid, and fair communication, we can have good leaders among all of these individuals. So this study backs and seconds to some extent the theory of leader are born and to some extent also shows and believes that leaders are created as stated by Warren Bennis: The most hazardous leadership lore is that leaders are born, that there is a hereditary influence to leadership. That's gibberish; in fact, the contradictory is correct. Leaders are prepared rather than natural.

Study suggests that a project manager at Pakistani software houses has to deal with different stakeholders and also clients around the globe, hence a Manager must be a global leader, a person who knows the cross cultural diversity, who knows the environment, emotional leadership and followers ${ }^{\text {ee }}$ management and must be well versed and equipped with communication. All barriers which can stop him to go ahead must be overcome. Pakistani Software industry is also influenced by Pakistani culture. So in this context, whether transformational leaders and transactional leadership definitions show that a leader must be trustworthy, but during this study, the researcher has presented them as the most important variables. So by using these three moderators during his communication, a leader can motivate the individuals and teams to outperform and ultimately lift the organization and themselves to a glory of heights.

\section{References and notes:}

Allen, N., \& Meyer, J. (1990). Organizational socialization tactics: A longitudinal analysis of links to newcomers" commitment and role orientation. The A c a de my of Management Journal, 33(4), 847-58.

Allen, N., J., \& Meyer, J., P. (1996). Affective, continuance, and normative commitment to the organization: An examination of construct validity. Journal of Vocational Behavior, 49, 252-276.

Amsterdam, August 16, 2010, Authentic Leadership in Great Places to Work, University of Amsterdam.

Anna H. L. Nordström, Line B. Ramsing, 2010, Effective Leadership Communications with Emotional 4.Intelligence (EI), Leading with Emotional Intelligence.

Avery G.\& Ryan J. (2002): Applying situational leadership in Australia, Journal of Management Development, 21, 4, 242-262.

Bass M. (1990): From transactional to transformation leadership: learning to share the vision. Journal, Organizational dynamic 18, 3, 19 
Barrett, D.J. (2006b), Leadership communication: A communication approach for senior-level managers, In Handbook of Business Strategy, Emerald group publishing, Rice University, Houston, pp 385-390, [online]

Campbell, G.M. (2011), The complete idiot ${ }^{\text {ee }}$ g guide to project management, 5th ed, Alpha Books, Indianapolis,

IN.

Dick, B. (1997), Communication skills, [online], Available from www.aral.com.au/resources/communicn.html

Emmitt, S. and Gorse, C.A. (2007), Communication in construction teams, Taylor \& Francis, New York.

Fiedler, F.E. (1967), A theory of leadership effectiveness, McGraw-Hill, New York.

Gardner, W., L., Avolio, B., J., Luthans, F., May, D., R., \& Walumbwa, F.(2005). Can you see the real me? A a self-based model of authentic leader and follower development. Leadership Quarterly, 16; 343-372.

Hargie, O. (eds), (2007), The handbook of communication skills, 3rd ed, Routledge, New York.

Hauptfleisch, A.C., and Siglé, H.M. (2004), Structure of the built environment in South Africa, 3rd ed, CONQS Publishers, Hatfield.

Hersey, P. and Blanchard, K.H. (1972), Management of organizational behavior: Utilizing human resources, 2nd ed, Prentice-Hall, Englewood Cliffs.

John C. Maxwell, (1998), The 21 Irrefutable Laws of Leadership: Follow Them and People Will Follow You, Deluxe Edition, September

Kerzner, H. (2001), Project management: a systems approach to planning, scheduling, and controlling, 7th ed, Wiley, New York.

Kerzner, H. (2009), Project management: a systems approach to planning, scheduling, and controlling, 10th ed, Wiley, New York.

Laufer, A., Shapira, A., and Telem, D. (2008), "Communication in dynamic conditions: how to do on-site construction project managers do it?" Journal of Management in Engineering, Vol. 24 No.2, pp. 75-86.

Levine, C. (2007). Neural Correlates of Corporate camaraderie and Teamwork. Annals. New York Academy of Sciences. 1118: 102-108.

Liu, A., Fellows, R. and Fang, Z. (2003), "The power paradigm of project leadership", Construction Management and Economics, Vol. 21 No. 8, pp. 819-829.

Li, A \& Cropanzano, R. (2009). Fairness at the Group Level: Justice Climate and Intraunit Justice Climate, Journal of Management, Vol. 35 No. 3, June 2009 564-599.

Luthans, F. \& Avolio, B. (2009). The "Point" of positive organizational behavior. Journal of Organizational Behavior, 30, p. 291-307.

Mark T. (1997) Mastering People Management, Build a Successful Team: Motivate, Empower and Lead People. p 29 \& 31.

Mabelo, P. (2011), When things fall apart, The Project Manager, pp. 22-28, March.

Macik-Frey, M. \&, Campbell Quick, J. \& Cooper, C.L. (2009). Authentic leadership as a pathway to positive health. Journal of Organizational Behavior, 30, p. 453-458. 
Maertz, C.P. \& Griffeth, R.W. \& Campbell, N.S. \& Allen, D.G. (2007). The effects of perceived organizational support and perceived supervisor support on employee turnover. Journal of Organizational Behavior 28, 1059-1075.

Meyer, E., Ashleigh, M., George, J.M., Jones, G.R. (2007) Contemporary Management, European edition. McGraw-Hill Education (UK).

Miners, T.W. (1969), Communications and cost control in the building industry with special reference to the role of the Quantity Surveyor, Thesis (D QuantSurv), University of Pretoria, Pretoria.

Morgan, G (2006) "Images of Organization", Sage Publications Inc., Thousand Oaks, CA

Müller, R. and Turner, R. (2010), “Leadership c om peten c y profiles of successful project managers", International Journal of Project Management, Vol. 28 No. 5, pp. 437-448.

Mumin Dayan1, C. Anthony Di Benedetto2 and Mustafa Colak. 2009, Managerial trust in new product development projects: its antecedents and consequences, Journal compilation (2009) Blackwell Publishing Ltd.

Odusami, KT. (2002), "Perception of construction professionals concerning important skills of effective project leaders", Journal of Management in Engineering, Vol. 18 No. 2, pp. 61-67.

Pllana, M. (2013). Leadership Style and the Relationship between Communication Satisfaction and Organizational Commitment: The Case of BP Home Company: Master's Thesis (Doctoral dissertation, M. Pllana).

Prof. Dr. Didier Cossin \& Dr. Jose Caballero, June 2013, Transformational Leadership, Background Literature Review.

Reinout E. de Vries, Angelique Bakker-Pieper, Wyneke Oostenveld, 2010, Leadership 5 Communication? The Relations of Leaders"Communication Styles with Leadership Styles, Knowledge Sharing and Leadership Outcomes, J Bus Psychol (2010) 25:367-380, DOI 10.1007/s10869-009-9140-2

Salovey, P. and Meyer, J.D. (1997). "What is Emotional Intelligence?" In P. Salovey and D. Sluyter (Eds.) Emotional Development and Emotional Intelligence: Implications for educators (p. 3-31). New York: Basic Books.

Santtu Toivonen and Grit Denker. 2004, The Impact of Context on the Trustworthiness of Communication: An Ontological Approach, In Proceedings of the ISWC Workshop on Trust, Security, and Reputation on the semantic web (2004). 


\title{
Summary
}

\section{Traitsof leadershipfor efficacious communication of Project Management in Software industry of Pakistan}

\author{
Muhammad Ibrahim Abdullah \\ COMSATS Institute of Information Technology, Pakistan
}

\author{
Muddassar Sarfraz \\ Hohai Business School, Hohai University, Jiangsu, PR China
}

\author{
Syed Murtaza HussainKazmi \\ COMSATS Institute of Information \& Technology (Virtual), Pakistan
}

This study aims at exploring the essential personas a project manager as a leader must possess for an effective communication. This study has been conducted in the context of Pakistani Software industry and the data was collected by running a self-administrated online survey distributed to the employees: managers and subordinates. Latest studies are focusing on Trustworthiness and old studies have presented Transformation and Transaction Leaders ${ }^{e e}$ traits. Communication is vital, and its importance cannot be denied. Communication must possess Trustworthiness, Fairness and Candidness factors which this study highlights and stresses to be as the most important traits of a PM. Pakistani Software industry lacks communication which results in failures of projects which can be overcome by applying an integrated model presented in this study. In conclusion, a project manager must evaluate and gather all the information according to the situation and after that apply proper skills to cope with that. Employees do much better if the right and correct information are transferred to them and the project manager/manager is trustworthy.

Keywords: Trustworthiness, Candidness, Fairness, Transformational, Communication 